\title{
Lithologically-related rare earth element variations the Mio-Pliocene Poznań Formation (Poland)
}

\author{
Jacek RETKA ${ }^{1, *}$ \\ 1 Polish Geological Institute - National Research Institute, Rakowiecka 4, 00-975 Warszawa, Poland
}

Retka, J., 2018. Lithologically-related rare earth element variations the Mio-Pliocene Poznań Formation (Poland). Geological Quarterly, 62 (1): 146-154, doi: 10.7306/gq.1388

Associate Editor - Stanisław Z. Mikulski

Concentrations of rare earth elements (REEs) were determined in 129 clay samples collected from the Mio-Pliocene Poznań Formation in Poland. The REEs occur in a relatively wide range from 58.2 to $1,709 \mathrm{mg} / \mathrm{kg}$. Low North American Shale Composite (NASC)-normalized total REE contents with heavy rare earth element (HREE) depletion were noted in most of the samples analysed. Small variations were detected in the REE contents in the lithologies distinguished. Red clays are characterised by slightly lower REE concentrations relative to green and grey clays. All the Poznań Formation clays exhibit a negative Eu anomaly when normalized to the average of chondrites. Values increase according to the following sequence: grey clays < red clays < green clays. The NASC-normalized REE concentration curves show a positive Eu anomaly. The $\mathrm{La}_{\text {NASC }} / \mathrm{Yb}_{\text {NASC }}$ ratio indicates HREE depletion. A small variation in this ratio was observed in the sequence green clays $>$ grey clays $>$ red clays. The variability of the REE contents of the Poznań Formation decreased from west to east.

Key words: Poznań Formation, rare earth elements, clay lithotypes.

\section{INTRODUCTION}

The Mio-Pliocene Poznań Formation (Poland), formerly called the Poznań Series, is situated in central and northern Poland and was formed in a large alluvial-lacustrine inland basin (Piwocki and Ziembińska-Tworzydło, 1997). The thickness of these deposits generally ranges from 40 to $60 \mathrm{~m}$ (Kozydra and Wyrwicki, 1970). The content of clay minerals is in the range of $35-90 \%$ (usually $50-60 \%$ ). Their composition is mainly dominated by smectites (beidellite-nontronite) and S/l (smectite-illite) mixed-layer minerals with subordinate illite and kaolinite. In the Poznań Formation, these clay minerals show a diverse compositional spectrum. In the northern and northeastern part, illite and beidellite prevail, with a predominance of beidellite. In the central part, the dominant components are illite and beidellite, and the amount of beidellite is notably reduced. Towards the coastal part of the basin, more sandy sediments occur in which the share of illite and I/S mixed-layer minerals increases. In the southern part of the area, the contribution of kaolinite also increases. In the foreland of the Sudetes this mineral is dominant (Wiewióra and Wyrwicki,

\footnotetext{
* E-mail: jacek.retka@pgi.gov.pl

Received: April 19, 2017; accepted: October 4, 2017; first published online: October 31, 2017
}

1974, 1976; Wichrowski, 1981; Brański, 1994, 2002; Nieć and Ratajczak, 2004).

Colour is used to discriminate between the three lithostratigraphic levels (units): grey clays, green clays, and red (bright red) clays (Wyrwicki, 1974; Nieć and Ratajczak, 2004). This is related to the presence of various iron minerals (Kozydra and Wyrwicki, 1970). The red-, russet-, and yellow-mottled colouring of red clays containing $6-14 \% \mathrm{Fe}_{2} \mathrm{O}_{3}$ is induced by the presence of hematite and goethite. Finely dispersed iron sulphides give a greyish-blue or greenish colour to the green clays. In the lower part of the grey clays, thin lignite (brown coal) interbeds also occur.

For hundreds of years the clay raw materials of the Poznań Formation have found wide applications. Currently, because of the relatively easy access to the deposits and their substantial thickness, these clays are used in building ceramics (Brański, 1994, 2012; Piwocki, 2002; Wyrwicki, 2002). Another application for the clays of the Poznan Formation is their use for the protection and restoration of the environment (Brański, 1994, 1998, 2002). Low permeability and high malleability, as well as good and very good sorption capacity, and the ion exchange properties of clays belonging to the beidellite and polymineral types make them suitable as an insulator material in landfills (Łuczak-Wilamowska, 2013).

The rare earth elements (REEs), also called lanthanides, are a family of fifteen elements from lanthanum to lutetium ( $\mathrm{La}$, $\mathrm{Ce}, \mathrm{Pr}, \mathrm{Nd}, \mathrm{Pm}, \mathrm{Sm}, \mathrm{Eu}, \mathrm{Gd}, \mathrm{Tb}, \mathrm{Dy}, \mathrm{Ho}, \mathrm{Er}, \mathrm{Tm}, \mathrm{Yb}$, and Lu) 
(Henderson, 1984). According to recommendations by the International Union of Pure and Applied Chemistry (IUPAC), scandium and yttrium are also included in the REE group (Connelly et al., 2005). The REEs, due to their similar chemical and geochemical properties, are a coherent series. REEs are usually divided into two conventionally termed groups:

- light REE (LREE) from La through to Eu;

- heavy REE (HREE) from Gd through to Lu.

There is also a third discriminated subgroup, medium REE (MREE) from Sm through to Ho, which partly overlaps the LREE and HREE (Migaszewski et al., 2016). Rare earth elements are highly dispersed and commonly occur in minerals that are very durable and resistant to weathering (Kabata-Pendias and Pendias, 1999). There are more than 250 minerals containing REE, including $\sim 70$ minerals in which REEs have a more specific role, for instance monazite-(Ce), (Ce, La, Nd, Th)[PO4], bastnäsite-(La) ( $\mathrm{La}, \mathrm{Ce})\left[\mathrm{F}, \mathrm{CO}_{3}\right]$, cheralite $\mathrm{Ca}_{0.5} \mathrm{Th}_{0.5}\left[\mathrm{PO}_{4}\right]_{2}$ and xenotime $\mathrm{Y}\left[\mathrm{PO}_{4}\right]$. The REEs have been produced from $\sim 20$ minerals, but only some of them are mined and processed (Paulo, 1999).

The mean REE content in clay sediments varies in a wide range from 79 to $259.7 \mathrm{mg} / \mathrm{kg}$ (Kabata-Pendias and Mukherjee, 2007). It varied in clay sediments primarily due to its lithology, genesis and age. In the Cretaceous and Pliocene sediments of central Portugal (kaolinite, illite and smectite deposits), the total content of $\mathrm{La}, \mathrm{Ce}, \mathrm{Sm}, \mathrm{Eu}, \mathrm{Tb}, \mathrm{Yb}$ and $\mathrm{Lu}$ varies from 190 to $323 \mathrm{mg} / \mathrm{kg}$ (Prudencio et al., 1989). The REE concentrations in the Eocene Oshosun Formation (southwestern Nigeria) - black and grey shale, and also clay - were in the range of 176.76-374.31 mg/kg (Ajayi et al., 2006). In Pliocene red loess clays from the Chinese Loess Plateau, a $\Sigma$ REE is lower - in range of $131-198 \mathrm{mg} / \mathrm{kg}$ (mean of $146 \mathrm{mg} / \mathrm{kg}$ ) (Ding et al., 2001). A similar range of REE content (139-252 mg/kg) was recorded in Cretaceous Shale taken from the vicinity of Corelato Perticara in the southern Apennines (Cavalante et al., 2014). In the Upper Cretaceous smectite, illite, and kaolin and mixed-layer illite-smectite clay interbeds from western Portugal (Aveiro and Taveiro regions), the total concentration of $\mathrm{La}, \mathrm{Ce}$, $\mathrm{Nd}, \mathrm{Sm}, \mathrm{Eu}, \mathrm{Tb}, \mathrm{Yb}$, and $\mathrm{Lu}$ varied from 66.1 to $272 \mathrm{mg} / \mathrm{kg}$ (Marques et al., 2011). Much higher REE contents were noted in the older clay deposits. Studies of the Havensville and Eskridge shales from Kansas and Oklahoma dated from the Lower Permian (marine) - encompassing montmorillonite, kaolinite, and illite - showed the presence of $\Sigma$ REE in the range of $5.4-1,732 \mathrm{mg} / \mathrm{kg}$ (Cullers et al., 1975). In Precambrian clay-rich strata from the Buwambo kaolin deposit (central Uganda), in which kaolinite is the dominant mineral, the REE contents ranged from 70.18 to $2,186 \mathrm{mg} / \mathrm{kg}$ (Nyakairu et al., 2001). Unlike in sedimentary clay deposits, it has been observed that (some) residual clays contain higher levels of REEs, up to several thousand milligrams per kilogram, marking these clay rocks as potential REE ore deposits (Foley et al., 2014; Yuan et al., 2014). For instance, in the Xuanwei Formation the total REE concentrations were in a wide range of 89.0 to $9,965 \mathrm{mg} / \mathrm{kg}$ (Zhang et al., 2016).

The purpose of the present study conducted in the Mio-Pliocene Poznań Clay Formation was to:

- determine current REE concentrations in the Poznań clays;

- to describe variations of REE contents in different parts of the alluvial-lacustrine basin;

- to establish the relationships between the REE contents and the different lithologies.

\section{SAMPLES AND METHODS}

129 samples were collected from 18 clay deposits: Bojanice, Brzostów, Budy Mszczonowskie, Chwalimierz II, Cienia I, Fordon, Gozdnica, Kunice III, Mirostowice Dolne, Nietążkowo I, Rudak I, Sierakowice, Stopka II, Słowiany, Sośnica, Szydłów II, Tadeuszów-Rudzienko, and Witaszyce (Fig. 1 and Table 1). Samples were collected from vertical profiles in all deposits, except for the Witaszyce deposit.

After acid digestion (using a mixture of $\mathrm{HNO}_{3}, \mathrm{HClO}_{4}, \mathrm{HF}$ ), the REE (La, Ce, Pr, Nd, Sm, Eu, Gd, Tb, Dy, Ho, Er, Tm, Yb, $\mathrm{Lu}$ ) concentrations were determined using inductively coupled plasma-quadruple mass spectrometry (ICP-QMS; model ELAN $D R C$ II, Perkin Elmer). Due to polyatomic interferences in the multi-element technique (ICP-QMS), mathematical corrections were applied to eliminate spectral interferences. In addition, to minimise matrix effects, samples were diluted tenfold prior to measurement. The analysis was performed in the presence of an internal standard (Rh and $\mathrm{Re}$ ) solution. Quality control included double digestion of selected samples and double sample measurements. The relative standard deviation (RSD) values were $<3 \%$ for most of the samples analysed. The estimated limit of quantification of $\mathrm{La}, \mathrm{Ce}, \mathrm{Pr}$, and $\mathrm{Nd}$ was $0.5 \mathrm{mg} / \mathrm{kg}$, and for Sm, Eu, Gd, Tb, Dy, Ho, Er, Tm, Yb, Lu it was 0.05 mg/kg.

The measured concentrations of REE in the Poznań Formation were normalized to average chondrite and to North American Shale Composite (NASC) (Gromet et al., 1984; Piper and Bau, 2013). For all samples the value of the europium anomaly - the enrichment or depletion of the europium content in minerals relative to the content of other REEs - was calculated. In order to investigate the enrichment or depletion in light rare earth elements (LREEs) and heavy rare earth elements (HREEs) of various clay lithologies in the Poznań Formation, $\mathrm{La} / \mathrm{Yb}$ and $\mathrm{La} / \mathrm{Sm}$ ratios were calculated. To determine these ratios, their normalized content in the clays tested was used.

Statistical parameters (mean, geometric mean, median, minimum, and maximum values) were determined using Statistica. This software was also used to develop histograms and determine REE, Eu/Eu*, La/Yb, and La/Sm ratios.

\section{RESULTS AND THEIR COMPARISON WITH DATA FROM OTHER FORMATIONS}

REE contents in the Poznań Formation range from 58.2 to $1,709 \mathrm{mg} / \mathrm{kg}$, with a mean of $176 \mathrm{mg} / \mathrm{kg}$, a geometric mean of $150 \mathrm{mg} / \mathrm{kg}$, and a median of $140 \mathrm{mg} / \mathrm{kg}$ (Table 2). The mean contents of individual elements were as follows (in $\mathrm{mg} / \mathrm{kg}$ ): La (32.0), $\mathrm{Ce}$ (80.6), $\operatorname{Pr}(8.40), \mathrm{Nd}$ (32.4), Sm (6.53), Eu (1.38), Gd (4.98), Tb (0.73), Dy (4.1), Ho (0.75), Er (2.02), Tm (0.26), Yb (1.68), and Lu (0.25). The REE concentrations varied substantially in clays of different deposits. The highest mean content was found in clays from the Sośnica deposit (geometric mean of $260 \mathrm{mg} / \mathrm{kg}$ ), and the lowest in the Chwalimierz II deposit (geometric mean of $78.5 \mathrm{mg} / \mathrm{kg}$; Table 2). The greatest REE concentration variability was noted in the Sośnica deposit, and the smallest in the Stopka II deposit (Table 2).

The Poznań Formation is characterized by a high variability of REE contents. This is particularly evident in relation to Cretaceous and Pliocene deposits from central Portugal and Cretaceous shales from the southern Apennines (Prudencio et al., 1989; Marques et al., 2011; Cavalante et al., 2014). It was 


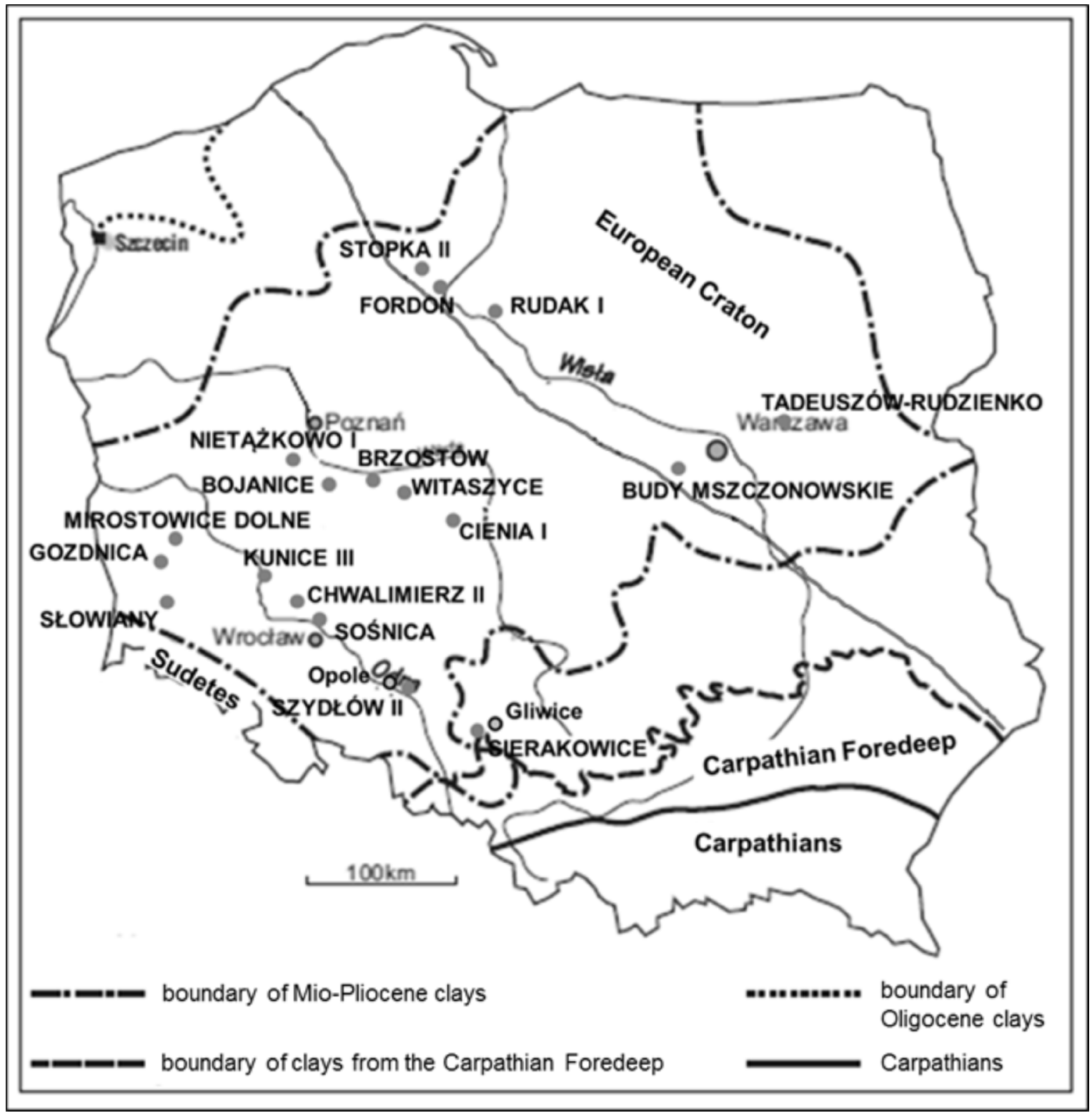

Fig. 1. Study area with Mio-Pliocene clay deposit locations

found that REE concentrations determined in different deposits (except for Brzostów and Witaszyce) of the Poznań Formation examined by Duczmal-Czernikiewicz (2012) is in line with their average contents in clays and shales. An average REE content similar to that of the Poznań clays was reported from coal-bearing deposits in Arkagalinskoe and Dolinskoe, where it is 172.07 mg/kg (Koporulin et al., 2007). In the Poznań Formation, the maximum $\Sigma$ REE content $(\sim 1,700 \mathrm{mg} / \mathrm{kg})$ is nearly the same as that found in the Lower Permian shale layers of Havensville and Eskridge (Kansas and Oklahoma) (Cullers et al., 1975). However, the minimum content of the Poznań clays is nearly 10 times higher.

The REE concentrations normalized to average chondrite exhibit an enrichment of these elements (from several times to $>100$ times). The NASC-normalized REE concentration patterns indicate that most of the samples analysed are depleted in HREEs (Fig. 2). The curves for all the deposits exhibit a slight enrichment in Ce and depletion in Tb, Ho, and Tm (Fig. 3). The highest depletion of HREEs is seen in the Mirostowice Dolne, Witaszyce and Sośnica deposits and the lowest in the Chwalimierz II and Kunice III deposits.

NASC-normalized REE concentration curves show enrichment in La, Ce, Pr, and Nd, especially in the Mirostowice Dolne, Sośnica and Witaszyce deposits, and depletion of these elements in the Chwalimierz II and Kunice III deposits.

The study shows that the value of europium anomalies in the Poznań clays is higher than in Portuguese Paleogene and Miocene clays, in which the Eu/Euchondrite* ratios range from 0.48 to 0.69 , and is also higher than in the loess from the Liyang Plain in southern China (0.63-0.67) (Mao et al., 2011; Lisboa et al., 2015). The value of europium anomalies in Poznań Formation clays is comparable or even lower than in significantly older Permian clays from deposits in Iran where Eu/Euchondrite* ratios range from 0.79 to 1.34 (Mahjoor et al., 2009).

It was found that the Lachondrite/Ybchondrite ratio in the Poznań Formation indicates LREE enrichment. The value of 
List of clay deposits of the Poznań Formation studied and their location, number of samples collected, and lithology

\begin{tabular}{|c|c|c|c|c|}
\hline No. & Deposit & Location & $\begin{array}{c}\text { No. } \\
\text { of samples }\end{array}$ & Lithology \\
\hline 1 & Bojanice & $\begin{array}{l}\text { Krzemieniewo municipality, } \\
\text { Leszno district }\end{array}$ & 6 & red, grey, bluish clays \\
\hline 2 & Brzostów & Jaraczewo municipality, Jarocin district & 7 & red, olive, greenish clays \\
\hline 3 & Budy Mszczonowskie & $\begin{array}{c}\text { Radziejowice municipality, } \\
\text { Żyrardów district }\end{array}$ & 7 & red, greenish clays \\
\hline 4 & Chwalimierz II & $\begin{array}{c}\text { Chwalimierrz municipality, } \\
\text { Środa Śląska district }\end{array}$ & 6 & red clays \\
\hline 5 & Cienia I & Opatówek municipality, Kalisz district & 7 & red, bluish clays \\
\hline 6 & Fordon & Bydgoszcz & 7 & red, grey, olive-grey clays \\
\hline 7 & Gozdnica & Żagań district & 8 & grey, green clays \\
\hline 8 & Kunice III & Legnica district & 7 & red, greenish clays \\
\hline 9 & Mirostowice Dolne & Żary municipality, Żary district & 8 & grey, bluish, greenish clays \\
\hline 10 & Nietążkowo I & Śmigiel municipality, Kościan district & 8 & red, grey, yellow-brown clays \\
\hline 11 & Rudak I & Toruń & 8 & red-brown, greenish, greenish-yellow clays \\
\hline 12 & Sierakowice & Sośnicowice municipality, Gliwice district & 8 & red clays \\
\hline 13 & Słowiany & Bolesławice district & 7 & red yellow-grey clays \\
\hline 14 & Sośnica & $\begin{array}{c}\text { Kąty Wrocławskie municipality, } \\
\text { Wrocław district }\end{array}$ & 7 & brown-light grey clays \\
\hline 15 & Stopka II & Koronowo municipality, Bydgoszcz district & 7 & greenish, yellow-brown clays \\
\hline 16 & Szydłów II & Tułowice municipality, Opole district & 7 & red clays \\
\hline 17 & Tadeuszów-Rudzienko & Dobre municipality, Mińsk district & 7 & dark grey, greenish clays \\
\hline 18 & Witaszyce & Jarocin municipality, Jarocin district & 7 & greenish clays \\
\hline
\end{tabular}

Descriptive statistics for the total REE contents $(\mathrm{mg} / \mathrm{kg})$ of the samples

\begin{tabular}{|c|c|c|c|c|c|c|c|}
\hline No. & Deposit & Mean & Geometric mean & Median & Minimum & Maximum & Standard deviation \\
\hline 1 & Bojanice & 230 & 195 & 161 & 110 & 455 & 148 \\
\hline 2 & Brzostów & 149 & 138 & 126 & 85.4 & 279 & 67.3 \\
\hline 3 & Budy Mszczonowskie & 148 & 144 & 135 & 107 & 226 & 42.9 \\
\hline 4 & Chwalimierz II & 79.0 & 78.5 & 78.3 & 67.3 & 91.6 & 9.38 \\
\hline 5 & Cienia I & 161 & 158 & 172 & 94.3 & 190 & 32.9 \\
\hline 6 & Fordon & 187 & 174 & 163 & 110 & 366 & 85.3 \\
\hline 7 & Gozdnica & 162 & 155 & 138 & 118 & 256 & 50.9 \\
\hline 8 & Kunice III & 101 & 96.6 & 85.1 & 73.9 & 164 & 33.4 \\
\hline 9 & Mirostowice Dolne & 295 & 270 & 227 & 166 & 545 & 139 \\
\hline 10 & Nietążkowo I & 140 & 132 & 129 & 81.4 & 282 & 60.8 \\
\hline 11 & Rudak I & 140 & 135 & 140 & 86.0 & 213 & 38.5 \\
\hline 12 & Sierakowice & 159 & 146 & 143 & 83.7 & 277 & 68.4 \\
\hline 13 & Słowiany & 125 & 119 & 137 & 58.7 & 165 & 37.8 \\
\hline 14 & Sośnica & 429 & 260 & 200 & 125 & 1709 & 579 \\
\hline 15 & Stopka II & 131 & 131 & 128 & 122 & 147 & 8.67 \\
\hline 16 & Szydłów II & 154 & 153 & 151 & 138 & 176 & 15.5 \\
\hline 17 & Tadeuszów-Rudzienko & 130 & 121 & 122 & 82.9 & 240 & 56.9 \\
\hline 18 & Witaszyce & 244 & 227 & 249 & 107 & 376 & 92.8 \\
\hline
\end{tabular}

this ratio is higher than in the Portuguese Paleogene and Miocene clays (5.4-11.9; Lisboa et al., 2015), and in Iran's Permian clays (7.1-10.8; Mahjoor et al., 2009).

The analysis of the calculated La/Sm ratio normalized to average chondrite and NASC shows a LREE enrichment in the Poznań Formation, although in case of the latter this ratio is low.
By comparison, the value of this ratio (chondrite-normalised) in the Portuguese Paleogene and Miocene deposits was in the range of 2.0 to 3.4 (Lisboa et al., 2015).

The study of the Poznań Formation clay lithologies shows that red clays have slightly lower REE concentrations in relation to the other two lithologies (Table 3). Green clays are abundant 


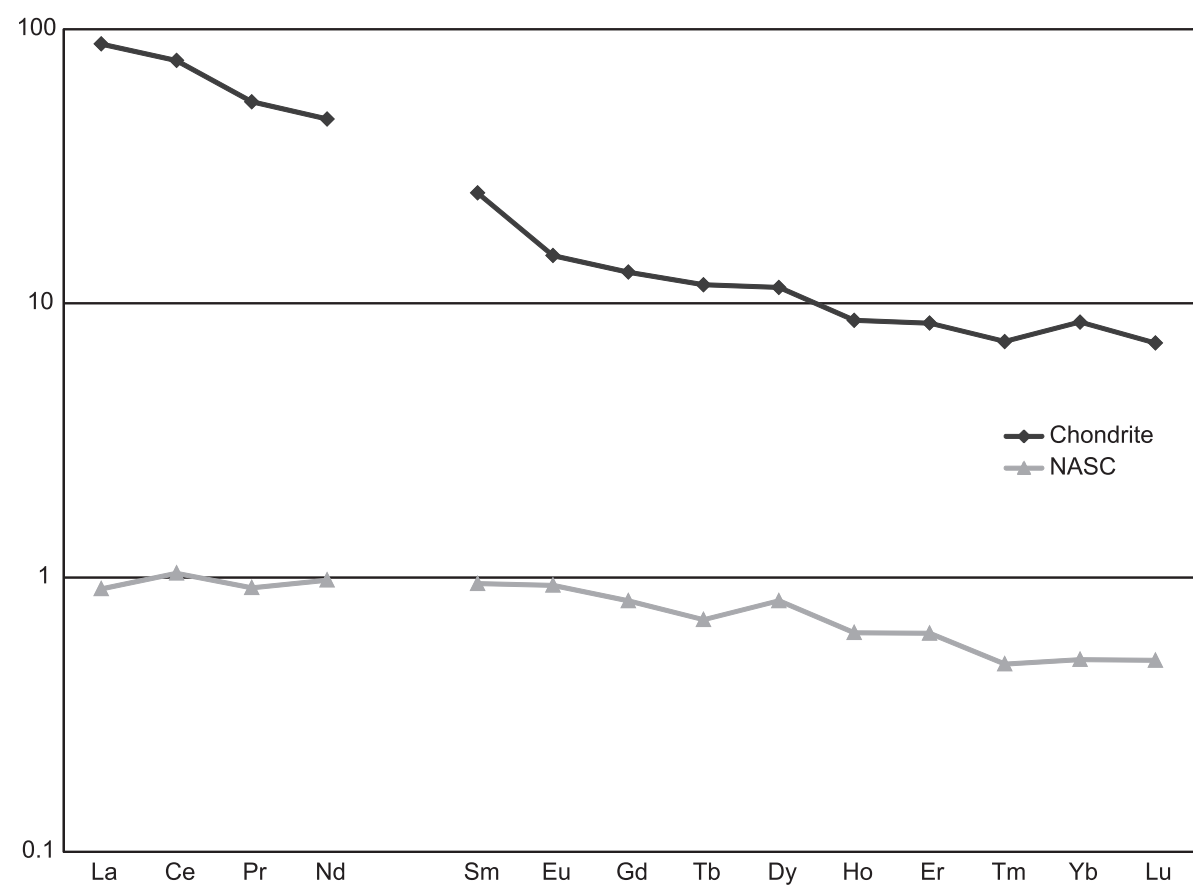

Fig. 2. REE concentration curves for all the clays examined normalized to chondrite and to NASC

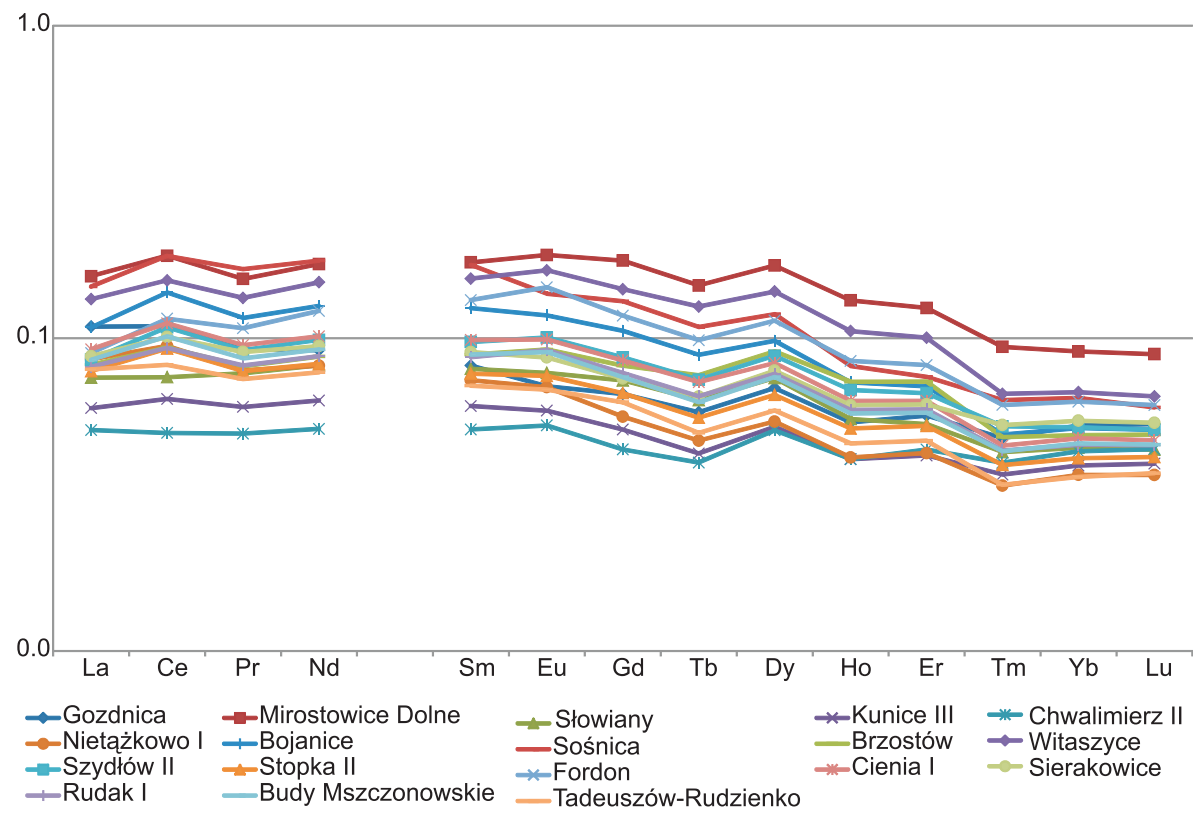

Fig. 3. The NASC-normalized REE concentration curves from all the clay deposits

in REEs from 82.9 to $376 \mathrm{mg} / \mathrm{kg}$. Their average content is $173 \mathrm{mg} / \mathrm{kg}$ (geometric mean: 159, median: $155 \mathrm{mg} / \mathrm{kg}$ ), while the REE contents in grey clays range from 83.9 to $545 \mathrm{mg} / \mathrm{kg}$ and the mean is $177 \mathrm{mg} / \mathrm{kg}$ (geometric mean: 158, median: $142 \mathrm{mg} / \mathrm{kg}$ ). In red clays the REE concentrations vary from 58.7 to $1,709 \mathrm{mg} / \mathrm{kg}$ and the average value is $178 \mathrm{mg} / \mathrm{kg}$, while the geometric mean $(140 \mathrm{mg} / \mathrm{kg})$ and the median $(133 \mathrm{mg} / \mathrm{kg})$ are much lower.

In all clay lithologies, samples with REE contents that vary from 100 to $150 \mathrm{mg} / \mathrm{kg}$ are most common (Fig. 4).

The REE concentration curves of the green, grey, and red clays normalized to the chondrite average and to NASC do not 
Table 3

Geometric mean REE contents (mg/kg) in the Poznań Formation lithologies

\begin{tabular}{|c|c|c|c|}
\hline Element & Green clays & Grey clays & Red clays \\
\hline $\mathrm{La}$ & 29.8 & 30.0 & 26.2 \\
\hline $\mathrm{Ce}$ & 73.8 & 72.9 & 63.9 \\
\hline $\mathrm{Pr}$ & 7.42 & 7.40 & 6.62 \\
\hline $\mathrm{Nd}$ & 28.4 & 27.9 & 25.0 \\
\hline $\mathrm{Sm}$ & 1.20 & 1.10 & 1.05 \\
\hline $\mathrm{Eu}$ & 5.61 & 5.45 & 5.02 \\
\hline $\mathrm{Gd}$ & 4.31 & 4.17 & 3.76 \\
\hline $\mathrm{Tb}$ & 0.63 & 0.61 & 0.56 \\
\hline $\mathrm{Dy}$ & 3.60 & 3.50 & 3.28 \\
\hline $\mathrm{Ho}$ & 0.67 & 0.65 & 0.61 \\
\hline $\mathrm{Er}$ & 1.86 & 1.81 & 1.70 \\
\hline $\mathrm{Tm}$ & 0.23 & 0.24 & 0.23 \\
\hline $\mathrm{Yb}$ & 1.52 & 1.58 & 1.52 \\
\hline $\mathrm{Lu}$ & 0.23 & 0.24 & 0.23 \\
\hline Total REE & 159 & 158 & 140 \\
\hline LREE & 146 & 145 & 128 \\
\hline $\mathrm{HREE}$ & 13.1 & 12.8 & 11.9 \\
\hline \multicolumn{4}{|l}{}
\end{tabular}

show any significant differences. It has been documented that all the Poznań Formation lithologies analysed exhibit a negative $\mathrm{Eu}$ anomaly when chondrite-normalized and a positive Eu anomaly when normalized to NASC.

The results obtained for the $\mathrm{Lac}_{\text {hondrite }} / \mathrm{Yb}_{\text {chondrite }}$ ratio in the three lithologies (Table 4) indicate that the green clays have slightly higher values. A ratio diversity was noted in each lithology, with green clays $>$ grey clays $>$ red clays, accordingly. The estimate of the $\mathrm{La}_{\text {chondrite }} / \mathrm{Sm}_{\text {chondrite }}$ ratio shows the highest value in grey clays.

\section{INTERPRETATION OF RESULTS}

The results were also analysed in terms of REE variability in the Poznan Formation within the sedimentary basin. The farther to the east of Poland, the REE concentrations were less diverse. A much greater variation in REE contents was observed in the western part of the basin. The highest REE concentrations were found in the Sośnica and Mirostowice Dolne deposits, and the lowest in Chwalimierz II and Kunice III, which are located in the vicinity of the REE-rich Sośnica deposit. Clays containing the largest amounts of REEs are from deposits in the Lubuski region (Mirostowice Dolne, Gozdnica, and Słowiany). These are genetically linked to the western part of the Precam-
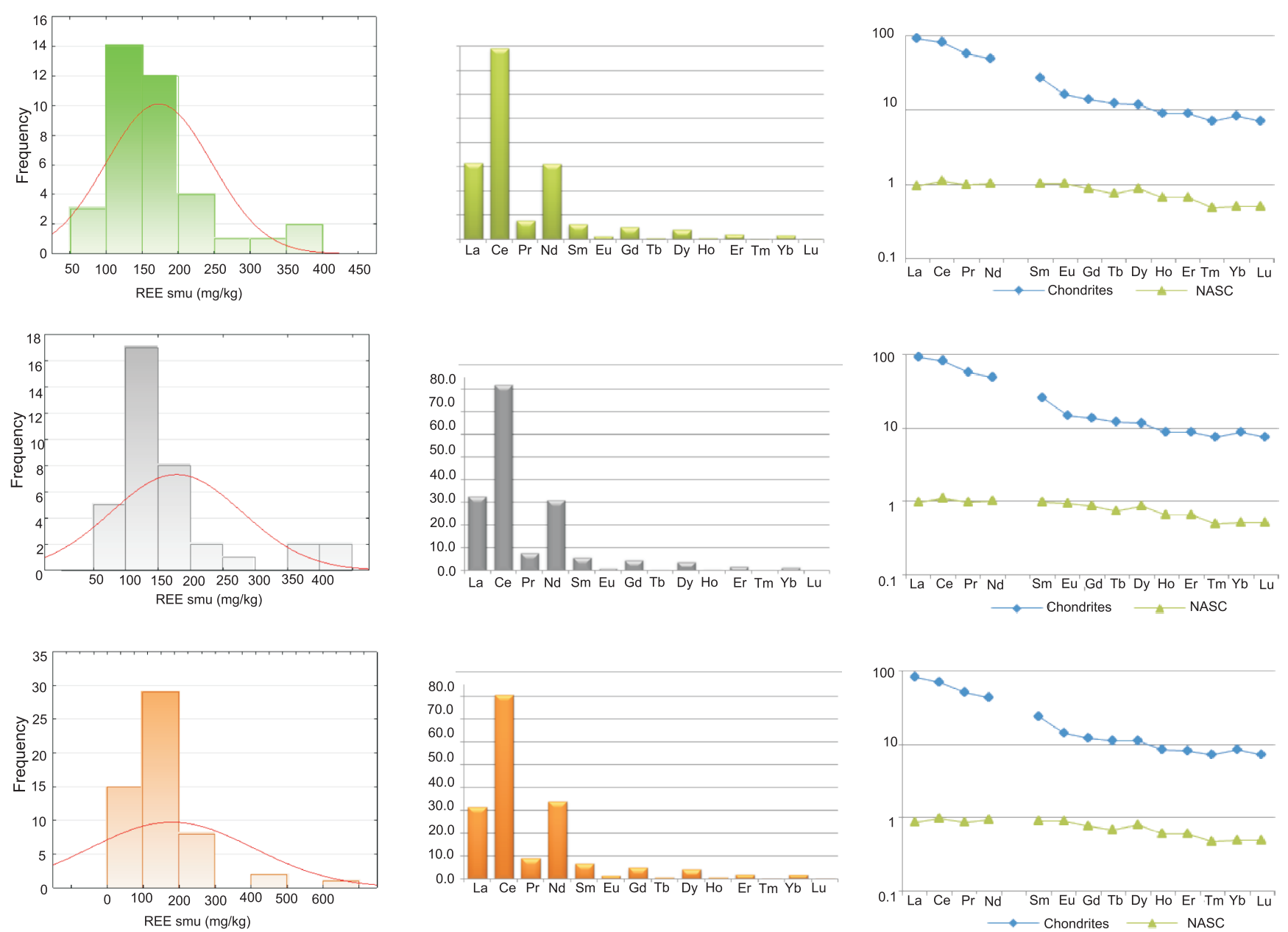

Fig. 4. Histograms, mean REE contents ( $\mathrm{mg} / \mathrm{kg}$ ), and REE concentration curves normalized to the chondrite average and to NASC in green, grey, and red clays 
Statistical parameters for Eu/Eu*, La/Yb, and La/Sm in the Poznań Formation

\begin{tabular}{|c|c|c|c|c|c|}
\hline Lithotype & Ratio & Mean & Geometric mean & Minimum & Maximum \\
\hline \multirow{2}{*}{ Green clays } & $\mathrm{Eu} / \mathrm{Eu}_{\text {chondrite }}{ }^{*}$ & 0.84 & 0.84 & 0.70 & 0.90 \\
\hline & $\mathrm{Eu} / \mathrm{Eu}_{\mathrm{NASC}}{ }^{*}$ & 1.26 & 1.25 & 1.05 & 1.34 \\
\hline \multirow{2}{*}{ Grey clays } & Eu/Eu chondrite $^{*}$ & 0.80 & 0.80 & 0.58 & 0.97 \\
\hline & $\mathrm{Eu} / \mathrm{Eu}_{\mathrm{NASC}}{ }^{*}$ & 1.19 & 1.19 & 0.87 & 1.45 \\
\hline \multirow{2}{*}{ Red clays } & $\mathrm{Eu} / \mathrm{Eu}_{\text {chondrite }}{ }^{*}$ & 0.83 & 0.83 & 0.56 & 0.93 \\
\hline & Eu/Eunasc* ${ }^{*}$ & 1.24 & 1.24 & 0.83 & 1.39 \\
\hline \multirow{2}{*}{ Green clays } & $\mathrm{La}_{\text {chondrite }} / \mathrm{Yb}_{\text {chondrite }}$ & 11.3 & 11.0 & 6.27 & 22.3 \\
\hline & $L a_{\text {NASC }} / Y b_{\text {NASC }}$ & 1.98 & 1.93 & 1.10 & 3.90 \\
\hline \multirow{2}{*}{ Grey clays } & $\mathrm{La}_{\text {chondrite }} / \mathrm{Yb}_{\text {chondrite }}$ & 11.0 & 10.7 & 5.23 & 15.6 \\
\hline & $\mathrm{La}_{\text {NASC }} / \mathrm{Yb}_{\text {NASC }}$ & 1.92 & 1.87 & 0.92 & 2.73 \\
\hline \multirow{2}{*}{ Red clays } & $\mathrm{La}_{\text {chondrite }} / \mathrm{Yb}_{\text {chondrite }}$ & 10.2 & 9.68 & 4.76 & 23.9 \\
\hline & $\mathrm{La}_{\mathrm{NASC}} / \mathrm{Yb}_{\mathrm{NASC}}$ & 1.78 & 1.69 & 0.83 & 4.19 \\
\hline \multirow{2}{*}{ Green clays } & $\mathrm{La}_{\text {chondrite }} / \mathrm{Sm}_{\text {chondrite }}$ & 3.57 & 3.49 & 1.70 & 5.25 \\
\hline & $\mathrm{La}_{\text {NASC }} / \mathrm{Sm}_{\text {NASC }}$ & 1.31 & 1.28 & 0.62 & 1.93 \\
\hline \multirow{2}{*}{ Grey clays } & $\mathrm{La}_{\text {chondrite }} / \mathrm{Sm}_{\text {chondrite }}$ & 3.71 & 3.61 & 1.75 & 5.19 \\
\hline & $\mathrm{La}_{\mathrm{NASC}} / \mathrm{Sm}_{\mathrm{NASC}}$ & 1.36 & 1.33 & 0.64 & 1.91 \\
\hline \multirow{2}{*}{ Red clays } & $\mathrm{La}_{\text {chondrite }} / \mathrm{Sm}_{\text {chondrite }}$ & 3.49 & 3.42 & 1.99 & 4.82 \\
\hline & $\mathrm{La}_{\text {NASC }} / \mathrm{Sm}_{\text {NASC }}$ & 1.28 & 1.26 & 0.73 & 1.77 \\
\hline
\end{tabular}

brian Bohemian Massif (Sudetes) which mainly encompass metamorphic and magmatic rocks. Generally, the clays containing the smallest amounts of REEs are from the group of Wrocław deposits (Kunice III, Chwalimierz II). These were also supplied by the Bohemian Massif (Sudetes), but from its central part, which is made up of rocks of various rocks of varied petrology e.g. Precambrian shale and gneiss, and Upper Cretaceous sandstones. Clays from Sierakowice and Szydłów II (in the vicinity of Opole and Gliwice), characterized by average REE contents, were fed mainly from the western areas of the Carpathians fold belt. Clays from the Kujawski (Stopka II, Fordon, Rudak I) and Mazowsze (Budy Mszczonowskie, Tadeuszów-Rudzienko) regions were supplied from different areas of the East European Craton, with relatively low REE concentrations. Deposits located in the central part of the basin (Nietażkowo I, Bojanice, Brzostów, Witaszyce, Cienia I) probably had mixed sources, but also favourable conditions to increase REE accumulation.

In the Poznań Formation clays, as in all sedimentary rocks, the contents of rare earth elements depends on clastic material composition and its origin, i.e. the REE contents in the source rocks. This study has shown that in the Poznań Formation clays, no matter what clay lithology, the highest REE contents occur in the western part of the basin, in which a much greater variation in REE contents was also observed. This part of the basin was supplied from the Bohemian Massif (Sudetes), where the crystalline rocks, post-magmatic mineralisation, as well as sedimentary rocks occur. Lower and less variable REE contents were observed in the central and eastern parts of the basin, which were fed by the Carpathians and the East European Craton that consist of sedimentary rocks.

The characteristic colours of the clay lithologies of the Poznan Formation is related to the presence of various iron minerals. The red clays comprise $\mathrm{Fe}$ in the form of oxides and hydroxides - hematite and goethite. Deposition of clays under oxidising conditions (red clays) facilitated REE mobility from minerals and their scavenging by authigenic iron oxyhydroxides was relatively small. In these clays the iron concentration was the highest, while the median REE content was the lowest $(133 \mathrm{mg} / \mathrm{kg})$ and they characterize the highest share of samples containing REEs in the range of $50-100 \mathrm{mg} / \mathrm{kg}$. The green clays show significantly lower Fe contents (in the form of sulphide - pyrite). In contrast, the median REE content was the highest $(155 \mathrm{mg} / \mathrm{kg}$ ) and the highest number of samples with REE contents in the range of $150-200 \mathrm{mg} / \mathrm{kg}$. Sedimentation of clays under reducing conditions (green clays) constrained the release of REEs from allochthonous minerals (plagioclase, pyroxene, hornblende, and zircon, in which REEs were probably dispersed).

The elevated $L a_{\text {chondrite }} / \mathrm{Yb}_{\text {chondrite }}$ ratio, which indicates LREE enrichment, suggests that the presence of REEs in clays is associated with plagioclase debris (in which LREE enrichment compared to pyroxenes and amphiboles is characteristic), also other feldspars, and especially clay minerals (Taylor et al., 1983; McLennan, 1989; McLennan et al., 1993). Small differences for each lithology was found in the series of green > grey $>$ red clays.

\section{CONCLUSIONS}

The REE contents in the Poznań Formation ranged from 58.2 to $1,709 \mathrm{mg} / \mathrm{kg}$, with a mean of $176 \mathrm{mg} / \mathrm{kg}$, a geometric mean of $150 \mathrm{mg} / \mathrm{kg}$, and a median of $140 \mathrm{mg} / \mathrm{kg}$. Clays from the Poznań Formation are characterized by REE contents similar to those from other clay deposits. 
Little diversification of REE contents was found in the different Poznań Formation clay lithologies. Red clays had slightly lower REE concentrations compared to green and grey clays. Total REE values for green and grey clays can be considered similar.

Different REE concentrations were found in different deposits. The highest mean content was in Mirostowice Dolne (geometric mean $-270 \mathrm{mg} / \mathrm{kg}$ ), and the lowest in Chwalimierz II (geometric mean $-78.5 \mathrm{mg} / \mathrm{kg}$ ).

Poznań Formation deposits are characterized by the enrichment of REE as compared to the chondrite pattern, visible in the graphs of their normalized average content. At the same time these clays are characterized by impoverishment in REE compared to the NASC pattern. All lithotypes of the Poznań Formation show negative chondrite-normalized Eu anomalies. NASC normalization exhibited a positive Eu anomaly.
The $L \mathrm{a}_{\text {chondrite }} / \mathrm{Yb}_{\text {chondrite }}$ ratio indicates LREE enrichment. Small differences among the lithologies was found in the pattern: green $>$ grey $>$ red clays.

Acknowledgements. The REE analysis in the Poznań Formation clays was possible by courtesy of Prof. I. Bojakowska and Dr. P. Brański. The author is grateful for being given access to the samples and to the major and trace element results from the project "Variability of the content of trace selected traces elements in Poznań series clays in sedimentation basin" (61.3207.0901.00.0). The present study is based on the author's doctoral dissertation "Ocena zmienności geochemicznej pierwiastków ziem rzadkich $w$ iłach serii poznańskiej w aspekcie ich litotypów" (in Polish) under the supervision of Prof. I. Bojakowska defended at the Polish Geological Institute - National Research Institute. I would like to thank all the reviewers (Z.M. Migaszewski, V. Lisboa and P. Brański) sincerely for their efforts in preparing the revised version of this paper.

\section{REFERENCES}

Ajayi, T.R., Oyawale, A.A., Islander, F.Y., Ausbiojo, O.I., Klein, D.E., Adediran, A.I., 2006. Trace and rare earth elements geochemistry of Oshosun sediments of Dahomey Basin, southwestern Nigeria. Journal of Applied Science, 6: 2067-2076.

Brański, P., 1994. Możliwości wykorzystania iłów serii poznańskiej w ochronie środowiska (in Polish). Przegląd Geologiczny, 42: 446-449.

Brański, P., 1998. Badania trzeciorzędowych iłów o podwyższonej zawartości smektytów (montmorylonitu) (in Polish). In: Ochrona litosfery (ed. S. Kozłowski): 197-200. Państwowy Instytut Geologiczny.

Brański, P., 2002. Iły formacji poznańskiej kopaliny służące ochronie i rekonstrukcji środowiska naturalnego (in Polish). Przeglad Geologiczny, 50: 266.

Brański, P., 2012. Distribution of the prognostic and perspective resources of building ceramics raw materials in Poland (in Polish with English summary). Biuletyn Państwowego Instytutu Geologicznego, 448: 411-418.

Cavalante, F., Belviso, C., Piccarreta, G., Saverio, F., 2014. Grain-size control on the rare earth elements distribution in the late diagenesis of Cretaceous shales from the Southern Apennines (Italy). Journal of Chemistry, 2014: Article ID 841747.

Connelly, N.G., Damhus, T., Hartshorn, R.M., Hutton, A.T., 2005. Nomenclature of Inorganic Chemistry. IUPAC Recommendations 2005.

Cullers, R.L., Chaudhurii, S., Arnold, B., Lee, M., Wolfe, C., 1975. Rare earth distributions in clay minerals and in the clay-sized fraction of the Lower Permian Havensville and Eskridge shales of Kansas and Oklahoma. Geochimica et Cosmochimica Acta, 39: 1691-1703

Ding, Z.L., Sun, J.M., Yang, S.L., Liu, T.S., 2001. Geochemistry of the Pliocene red clay formation in the Chinese Loess Plateau and implications for its origin, source provenance and paleoclimate change. Geochimica et Cosmochimica Acta, 65: 901-913.

Duczmal-Czernikiewicz, A., 2012. Rare earth elements in selected clay deposits of the Polish Lowland (Neogene). Biuletyn Państwowego Instytutu Geologicznego, 448: 419-430.

Foley, N.K., Ayuso, R.A., Bern, C.R., Hubbard, B., Vazquez, J., 2014. REE distribution and mobility in regolith formed on granite bedrock, Southeast United States. Acta Geologica Sinica, 88 (suppl. 2): 428-430.
Gromet, L.P., Dymek, R.F., Haskin, L.A., Korotev, R.L., 1984. The "North American shale composite": its compilation major and trace element characteristics. Geochimica et Cosmochimica Acta, 48: 2469-2482.

Henderson, P., 1984. Rare Earth Element Geochemistry. Developments in Geochemistry, 2. Elsevier.

Kabata-Pendias, A., Mukherjee, A.B., 2007. Trace Elements from Soil to Human. Springer.

Kabata-Pendias, A., Pendias, H., 1999. Biogeochemia pierwiastków śladowych (in Polish). PWN.

Koporulin, V.I., Lyapunov, S.M., Seredin, V.V., 2007. Rare earth elements in the clay fraction of coaliferous sediments of the Arkagalinskoe (Magadan District) and Dolinskoe (Sakhalin Island) coalfields. Lithology and Mineral Resources, 44: 483-496.

Kozydra, Z., Wyrwicki, R., 1970. Surowce ilaste (in Polish). Wyd. Geol., Warszawa.

Lisboa, J.V., de Oliveira, D.P.S., Rocha, F., Oliveira, A., Carvalho, J., 2015. Patterns of rare earth and other trace elements in Paleogene and Miocene clayey sediments from the Mondego platform (Central Portugal). Chemie der Erde, 75: 389-401.

Łuczak-Wilamowska, B., 2013. Geological conditions of municipal waste landfilling (in Polish with English summary). Biuletyn Państwowego Instytutu Geologicznego, 455: 1-142.

Marques, R., Dias, M.I., Prudencio, M.I., Rocha, F., 2011. Upper Cretaceous clayey levels from western Portugal (Aveiro and Taveiro regions): clay mineral and trace-element distribution. Clay and Clay Minerals, 59: 315-327.

Mahjoor, A.S., Karimi, M., Rastegarlari, A., 2009. Mineralogical and geochemical characteristics of clay deposits from South Abarkouh District of clay deposit (Central Iran) and their applications. Journal of Applied Science, 9: 601-614.

Mao, L., Mo, D., Li, M., Zhou, K., Yang, J., Guo, W., 2011. The rare earth element compositions of sediments from loess tableland in the Liyang Plain, southern China: implications for province and weathering intensity. Environmental Earth Sciences, 62: 1609-1617.

McLennan, S.M., 1989. Rare earth elements in sedimentary rocks; influence of provenance and sedimentary processes. Reviews in Mineralogy and Geochemistry, 21: 169-200.

McLennan, S.M., Hemming, D., McDaniel, D.K., Hanson, G.N., 1993. Geochemical approaches to sedimentation, provenance, and tectonics. GSA Special Paper, 284: 21-40. 
Migaszewski, Z.M., Gałuszka, A., Dołęgowska, S., 2016. Rare earth and trace element signatures for assessing an impact of rock mining and processing on the environment: Wiśniówka case study, south-central Poland. Environmental Science and Pollution Research, 23: 24943-24959.

Nieć, M., Ratajczak, T., 2004. Złoża kopalin ilastych do produkcji ceramiki budowlanej, kruszyw lekkich i cementu (in Polish). In: Surowce mineralne polski. Surowce skalne. Surowce ilaste. (ed. R. Ney): 117-217. Wydawnictwo Instytutu GSMiE PAN.

Nyakairu, G.W.A., Koeberl, C., Kurzweil, H., 2001. The Buwambo kaolin deposit in central Uganda: mineralogical and chemical composition. Geochemical Journal, 35: 245-256.

Paulo, A., 1999. Pierwiastki ziem rzadkich pod koniec XX wieku (in Polish). Przegląd Geologiczny, 47: 34-41.

Piper, D.Z., Bau, M., 2013. Normalized rare earth elements in water, sediments, and wine: identifying sources and environmental redox conditions. American Journal of Analytical Chemistry, 4: 69-83.

Piwocki, M., 2002. Ewolucja poglądów na stratygrafię utworów formacji poznańskiej na Niżu Polskim (in Polish). Przegląd Geologiczny, 50: 255

Piwocki, M., Ziembińska-Tworzydło, M., 1997. Neogene of the Polish Lowlands lithostratigraphy and pollen-spore zones. Geological Quarterly, 41 (1): 21-40.

Prudencio, M.I., Figueiredo, M.O., Cabral, J.M.P., 1989. Rare earth distribution and its correlation with clay mineralogy in the clay-sized fraction of Cretaceous and Pliocene sediments (central Portugal). Clay Minerals, 24: 67-74.

Taylor, S.R., McLennan, S.M., Mcculloch, M.T., 1983. Geochemistry of loess, continental crustal composition and crustal model ages. Geochimica et Cosmochimica Acta, 47: 1897-1905.

Wichrowski, Z., 1981. Studium mineralogiczno-geochemiczne iłów serii poznańskiej (in Polish). Archiwum Mineralogiczne, 37: 93-106.

Wiewióra, A., Wyrwicki, R., 1974. Clay minerals in the mottled clay horizon of the Poznań series (in Polish with English summary). Kwartalnik Geologiczny, 18 (3): 615-635.

Wiewióra, A., Wyrwicki, R., 1976. Clay minerals of the Poznań series in the section of Rogaczewo (in Polish with English summary). Kwartalnik Geologiczny, 20 (3): 823-837.

Wyrwicki, R., 1974. Clay sediments of the Poznań Series as ceramic raw materials (in Polish with English summary). Biuletyn Instytutu Geologicznego, 280: 107-205.

Wyrwicki, R., 2002. Iły formacji poznańskiej jako surowce ceramiczne (in Polish). Przegląd Geologiczny, 50: 267-268.

Yuan, H., Li, S., Pei, Q., Ding, A., 2014. Research of weathering crust profile of REE deposit in Guposhan, Guangxi. Acta Geologica Sinica, 88 (suppl. 2): 1317-1318.

Zhang, Z., Zheng, G., Takahashi, Y., Wu, C., Zheng, C., Yao, J., Xiao, C., 2016. Extreme enrichment of rare earth elements in hard clay rocks and its potential as a resource. Ore Geology Reviews, 72: 191-212. 